\title{
Establishing the Database of Inundation Potential in Taiwan
}

\author{
ALBERT S. CHEN ${ }^{1,4, \star}$, MING-HSI HSU ${ }^{2}$, WEI-HSIEN TENG ${ }^{3}$, \\ CHEN-JIA HUANG ${ }^{1}$, SEN-HAE YEH ${ }^{1}$ and WAN-YU LIEN ${ }^{1}$ \\ ${ }^{1}$ Flood and Drought Disaster Reduction Division, National Science \& Technology Center for \\ Disaster Reduction, Taipei, Taiwan, ROC; ${ }^{2}$ Department of Bioenvironmental Systems Engi- \\ neering, National Taiwan University, Taipei, Taiwan, ROC; ${ }^{3}$ Department of Architecture, \\ National United University, Taiwan, ROC; ${ }^{4} 3 F$, No. 106, Sec. 2, Hoping E. Rd, Taipei, Taiwan, \\ ROC 106
}

\begin{abstract}
The structural measure was the major solution for flood defense in Taiwan. However, the measure is always limited to the design standard and cannot prevent the damages when floods exceed certain scale. Therefore, non-structural measures for flood mitigation are the indispensable complements to structural solutions. The study introduces the establishment of inundation potential database that provides required information for the non-structural measures in Taiwan. The database was built by numerical simulations, based on different rainfall scenarios, and has been applied by the local governments of Taiwan for land use managements, flood warning systems, emergency responses, and flood insurance programs to reduce the flood damages and impacts.
\end{abstract}

Key words: inundation potential, flood mitigation, overland flow model, non-structural measures, flood defense strategies

\begin{abstract}
Abbreviations: DEM - Digital Elevation Model; DTM - Digital Terrain Model; EA - Environment Agency of U.K.; EOI - Equivalent Occurrence Interval; EP - Exceedence Probability; FEMA Federal Emergency Management Agency of the USA; FIA - Federal Insurance Administration of the USA; GIS - Geographical Information System; NAPHM - National Science and Technology Program for Hazards Mitigation; NFIP - National Flood Insurance Program; SWMM - Storm Water Management Model; STSP - Southern Taiwan Science Park
\end{abstract}

\section{Introduction}

For sustainable development and environmental protection, non-structural measures have become popular solutions for flood hazard mitigation in the world (Changnon, 1998; Harman et al., 2002; Klijn et al., 2004). Japan and U.K., both are island countries with similar geographic conditions to Taiwan, have used the flood maps to set up the non-structural strategies. In Japan, the flood maps are important basis of the Basic Disaster Management

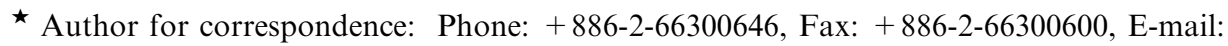
albertchen@ncdr.nat.gov.tw 
Plan (Cabinet Office, 2003). The sequence of disaster countermeasures including preparedness, emergency response, recovery and reconstruction is described in the plan. The duties of the Government, the public corporations and the local governments are also clarified in the plan. Based on the plan, the governments develop comprehensive flood control measures to mitigate the disaster impacts. In the U.K., the Environment Agency (EA) provides the flood mapping information to raise awareness that the areas could be flooded in certain conditions. EA also sets out the Strategy for Flood Risk Management, including flood warning, floodplain managements and flood insurance, according to the flood maps, to minimize the risk from flooding to life, property and the environment (Murphy, 2003).

The most complete flood risk mapping in actual practice is the National Flood Insurance Program (NFIP) in the USA, which was initiated by Congress in 1968 (Burby, 2001). The flood risk was distributed to both government and individuals that the homeowners in a floodplain require to buy insurance instead of government grants and loans. The administrator of the NFIP, the Federal Insurance Administration (FIA), which is a branch of the Federal Emergency Management Agency (FEMA), produces maps of participating NFIP communities that indicate areas in the communities with high flood risk. The successful program helps the governments and civilians to reduce the flood risks. The FEMA is embarking on applying the experience to modernize the flood maps and to develop multi-hazard maps (Lowe, 2003).

Besides flood maps, many non-structural measures were also adopted for flood hazard mitigations. For examples, the basin rainfall monitor system (Subramaniam and Kerpedjiev, 1998) and real time flow forecasting (Bae et al., 1995; Hsu et al., 2003) were adopted to assist the emergency managers for evaluating flood situations. The virtual database and decision support system were applied to the Red River basin in Canada (Simonovic, 2002) for providing a more transparent and efficient process in flood management to reduce the economic, environmental and social damages. The flood risk managements for land use were implemented in the Rhine basin in Europe (Bohm et al., 2004; Hooijer et al., 2004; Middelkoop et al., 2004), Camel catchment (Sullivan et al., 2004) and New South Wales (Yeo, 2003) in the U.K. The combinations of flood risk information and geographical information system (GIS) provide powerful tools for flood managements (Al-Sabhan et al., 2003; Gunes and Kovel, 2000; Zerger and Wealands, 2004).

Most non-structural measures require risk analyses, which are carried out by physical or numerical models, as the rational basis for flood-alleviation planning. In many applications, different approaches were adopted for flood risk assessments via hydrological, hydraulic or ecological models (National Science Foundation, 1980; Hooper and Duggin, 1996; Abbott, 1998; Djordjevic et al., 1999). The degrees of flood risk for flood-prone areas were identified by using these models. Accordingly, based on the 
flood risk information, the governments developed the policies for land use management, set the flood insurance premium rates and established the criteria for construction in alluvial plains.

In Taiwan, the island-wide inundation potential database was built by using a series of numerical models. The models were combined to reflect the hydrologic and hydraulic characteristics within a watershed, including the surface runoffs in upstream catchments, channel flows in rivers, overland flows on alluvial plains and sewer flows in drainage systems. The processes of building the inundation potential database in Taiwan and practical applications are reviewed in the study.

\section{Description of the Study Area}

The annual precipitation in Taiwan is about $2500 \mathrm{~mm}$ and more than $78 \%$ of the precipitation concentrates in monsoon and typhoon seasons during May to October (Water Resources Agency, 2003). The tremendous amount of rainfall accompanying typhoons often results in serious inundation. According to the official statistics, 152 typhoons that hit Taiwan occurred between 1958 and 2001 which resulted in 16,305 causalities (Lin, 2002). On an average, the number of floods that hit Taiwan was increased from 3.0 times per year in 1970s to 5.6 times per year in late 1990s (Table I). Although the authorities had increased investments in flood structural works, but the flood-damage losses did not slow down in trend $(\mathrm{Wu}$, 1995). Table II shows severe damages incurred by typhoons in Taiwan in recent years. In 2001, the intensive typhoons, named Trami, Toraji and Nari, resulted in 323 death and missing tolls within three months.

The major factor exacerbating the flood damages is the over-development of urban areas. For example, Lee et al. (1999) compared the satellite images of 1988 (Figure 1) and 1998 (Figure 2) of Sijhih City in the north of Taiwan and found that $16 \%$ of the city area was altered from cultivate and wood lands to buildings and roads in the decade (Lee et al., 1999), whereas the population

Table I. The flood disasters induced by typhoons and severe storms between 1972 and 2001 in Taiwan for each consecutive 5 years

\begin{tabular}{llllllll}
\hline \multirow{2}{*}{ Year } & \multicolumn{2}{l}{ Disasters in 5 years } & & \multicolumn{3}{l}{ Average disasters in a year (times) } \\
\cline { 2 - 3 } & Typhoon & Severe storm & Sum & & Typhoon & Severe storm & Sum \\
\hline $1972-1976$ & 11 & 4 & 15 & & 2.2 & 0.8 & 3.0 \\
$1977-1981$ & 13 & 5 & 18 & & 2.6 & 1.0 & 3.6 \\
$1982-1986$ & 16 & 3 & 19 & & 3.2 & 0.6 & 3.8 \\
$1987-1991$ & 21 & 7 & 28 & & 4.2 & 1.4 & 5.6 \\
$1992-1996$ & 21 & 6 & 27 & & 4.2 & 1.2 & 5.4 \\
$1997-2001$ & 23 & 5 & 28 & & 4.6 & 1.0 & 5.6 \\
\hline
\end{tabular}


Table II. Typhoon events caused heavy casualties in recent years

\begin{tabular}{llcr}
\hline Year & Typhoon event & Death/Missing & Injured \\
\hline 1996 & Herb & 73 & 463 \\
1997 & Winnie & 28 & 46 \\
1998 & Zeb, Babs & 17 & 8 \\
2000 & Xangsane & 89 & 65 \\
2001 & Trami, Toraji & 219 & 192 \\
2001 & Nari & 104 & 265 \\
2004 & Mindulle & 41 & 16 \\
\hline
\end{tabular}

increased $74 \%$ quickly, from 85,001 to 147,507 , within the same period (Sijhih City Household Registration Office, 2004). Most of the urbanized areas concentrated along the Keelung River and situated in the floodplains. As a result, the drainage condition of the watershed is worse for floodwaters due to the increased impervious pavements, shortening the time of concentration and raising the peak discharges of floods. Undoubtedly, Sijhih City has become one of the most frequently flooded areas in Taiwan.

Structural solutions usually provide an incorrect impression to civilians, even including the officers, that their lives and properties are free from being flooded. The following unbridled developments of urbanization often increase the flood risk for the residents. It forced the government to spend more budgets on structural works for re-strengthening their safeties. The vicious circle cannot solve the problems, contrarily,

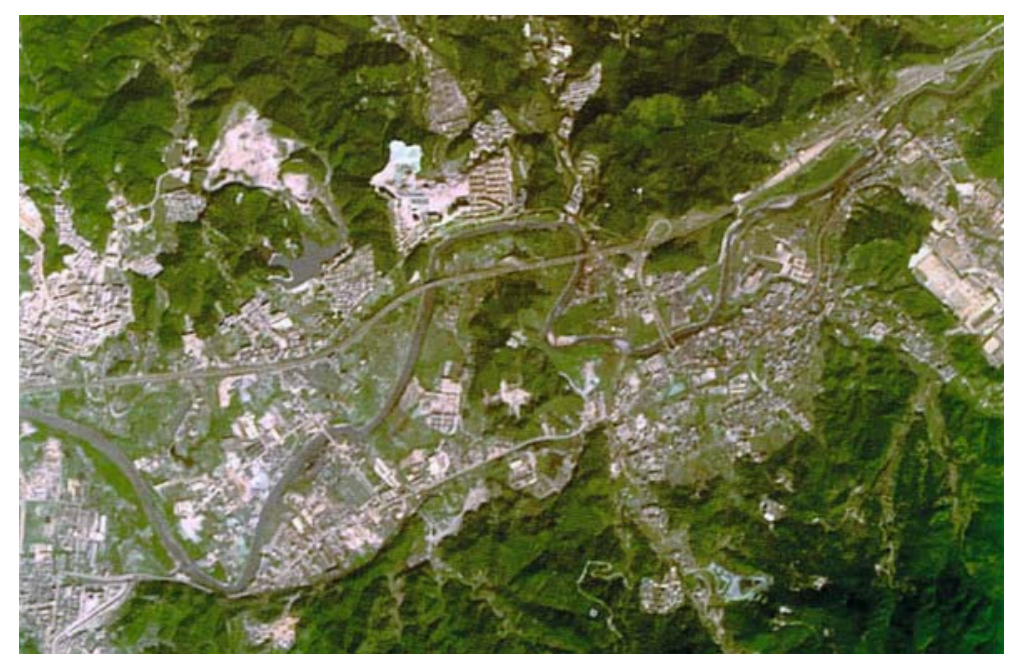

Figure 1. The satellite image of Sijhih City in 1988 (source: Center for Space and Remote Sensing Research, National Central University, Taiwan). 


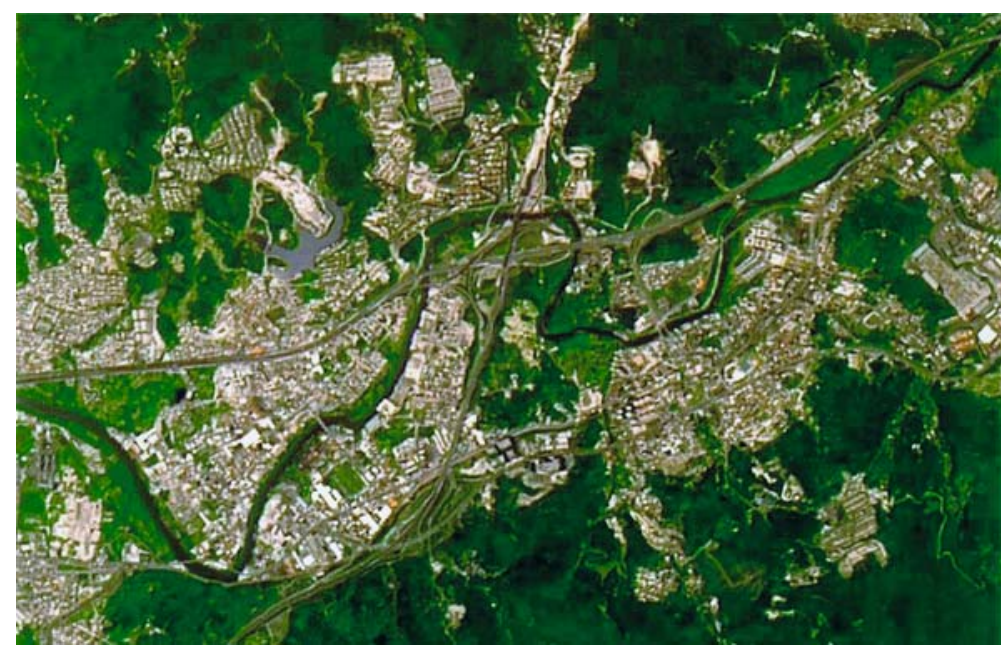

Figure 2. The satellite image of Sijhih City in 1998 (source: Center for Space and Remote Sensing Research, National Central University, Taiwan).

the environments and ecosystems are frequently damaged. Nowadays, like many developed countries, the Taiwan government and public realize that structural solutions are limited to prevent flood threaths. More non-structural measures such as alluvial plain managements, flood forecasting and warning systems, flood insurance programs and public awareness are introduced as the complement to mitigate flood risks in recent years.

In Taiwan, the National Science and Technology Program for Hazards Mitigation (NAPHM) launched the project to build the inundation potential database. The main goal of the project was to analyze the flood risk for improvement in the flood management around the island. The database has been finished and released to public for practical flood hazard prevention and mitigation.

\section{Methodology}

The inundation potentials were simulated by using a series of numerical models. The work was proceeded by watershed divisions individually. Geographically, Taiwan was split up into 53 watersheds for numerical simulations. Within a watershed, several numerical models were composed for hydrologic and hydraulic routings with different design rainfalls. Consequently, each watershed was divided into upstream mountain catch- 
ments, river channels, and downstream alluvial plains, with the assistance of GIS, for numerical model simulations.

\subsection{SURFACE RUNOFFS OF MOUNTAIN CATCHMENTS}

Upstream catchments of watersheds in Taiwan are mountainous with steep land slopes, the surface runoffs concentrate rapidly to channel flowing into downstream alluvial plain once the storm rainfall starts. The HEC-1 model (U.S. Army Corps of Engineers Hydrologic Engineering Center, 1992) was applied for hydrologic analysis. The excess rainfall hyetographs based on the Horton infiltration equation were used to compute the surface runoffs for mountain catchments, whereas the runoff hydrographs at catchments outlets were treated as boundary inputs for the numerical routing in river channels or downstream alluvial plains.

\subsection{CHANNEL FLOW OF RIVERS}

The flood flows in rivers can be described by the 1-D unsteady gradually varied flow equations (i.e. the St. Venant equation). A dynamic flood routing based on the 1-D continuity and momentum equations in open channels was developed by using the 4-point Preissmann scheme (Cunge et al., 1980). The model had been applied to several studies in Taiwan (Chang et al., 2000; Hsu et al., 2003). The model was performed herein to calculate the channel floods.

\subsection{OVERLAND FLOW OF ALLUVIAL PLAINS}

Assuming that the acceleration term of water flow on the land surface is small compared to gravitation and friction terms, the inertial term in the motion equations is neglected. Then, the shallow water flows on land surface can be described by 2-D depth-averaged non-inertial wave equations. In the study, the non-inertial model was adopted for solving the equations by the alternating direction explicit scheme (ADE), which allows calculations with zero water depth and velocity (Hsu et al., 1990). The authors had conducted a series of studies in Taiwan and found that the model could accurately simulate the overland flow characteristics of alluvial plains (Hsu, 1992, 1998; Hsu et al., 1998).

\subsection{SEWER FLOWS IN URBAN AREAS}

For the urban regions with sewer drainage systems, the Storm Water Management Model (Huber, 1975; Huber and Dickinson, 1988) was applied for sewer flow routing. The model is used to solve the storm sewer flow component and compute the surcharged discharge from sewers to the overland surface. The bidirectional interactions between sewer networks 
and ground surfaces were considered for linking the SWMM model and 2D overland flow models (Hsu et al., 2002).

\subsection{MODEL LINKAGES}

Figure 3 displays the simulation processes among models. The HEC-1 model was first routed to simulate runoff discharges of the upstream catchments. The discharges were considered as the upstream boundary conditions for routing in alluvial plains where the 2-D non-inertial model was used for overland flow simulations, 1-D channel dynamic model for river flows and SWMM for storm sewer system.

The flow interactions are set as internal boundary conditions between 1-D and 2-D, 2-D and SWMM models with the considerations of their relative water stages. The 1-D and 2-D models were linked by weir discharge formula for physical lateral weir connections (Chang et al., 2000). For some areas with high flood levees, the pumping stations were set to drain the inland water into channels during floods. Hence, the pumping discharges were also considered for such connections.

In township or urban areas with storm drainage systems, the surface drainage through inlets to sewer systems or the overflow from surcharged manholes to ground surface were used for model linkages between the overland flow and sewer routing models. The former is treated as the sink and the later as the source in the 2-D model. The source codes of SWMM were rewritten by the authors for dynamic coupling with the 2-D model. The detailed descriptions of the models can be found in the authors' earlier study (Hsu et al., 2002).

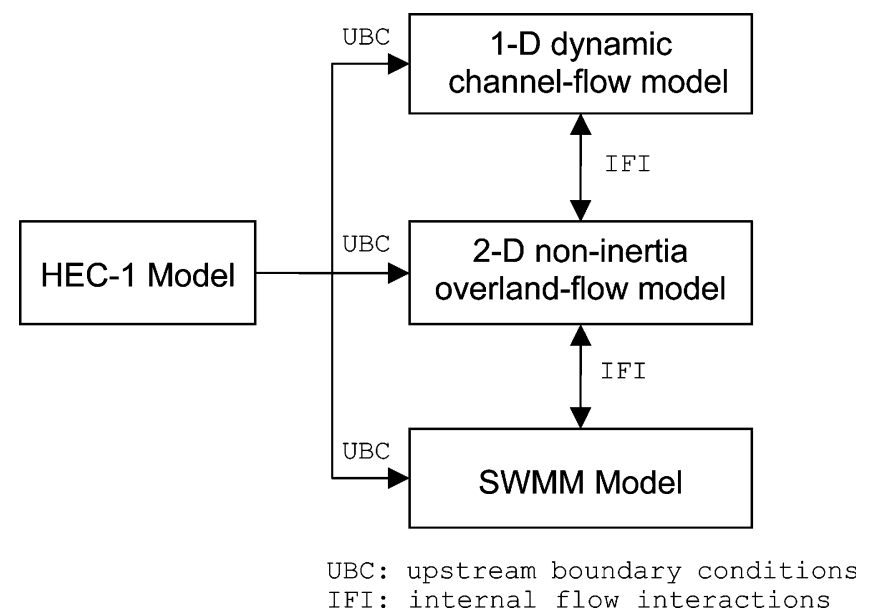

Figure 3. Relationships between numerical components for inundation potential simulations. 


\subsection{MODEL INPUTS}

The flood risk analysis had never been executed in the national scale before due to the great amount of input data required for numerical models. Fortunately, with the rapid advance in technology, the tedious work of data collection was simplified by using GIS, digital terrain model (DTM) and digital elevation model (DEM). Since the irregular nature of surface land area, it was usually easier to sample a rectilinear grid of a fixed size than to fit unstructured grid to the underlying topography (Bishop and Catalano, 2001). Meanwhile, the structuralized nature of a finite-difference grid costs less time and efforts for building detailed topography and roughness maps. Furthermore, the computing grids are more readily sampled for topography data and easier for fitting into raster-based GIS. To complete the large-scale project in three years, a grid size of $200 \mathrm{~m} \times 200 \mathrm{~m}$ was chosen as the compromise between accuracy and efficiency. There were two areas using a better grid resolution, $40 \mathrm{~m} \times 40 \mathrm{~m}$, including Taipei City where is the capital, and Sijhih City where is the most flood-prone area in Taiwan. The ground elevation and roughness of grids were extracted from DEM and DTM, respectively. The river channels, levees, storm sewer systems were mapped onto overland surface with the help of GIS for model linkages.

\section{Model Calibrations and Verifications}

In early years, the flood extents, depths and related information in Taiwan were seldom recorded during floods. The field surveys were only proceeded after major flood events, which resulted in severe damages such as huge life or financial losses. Meanwhile, most of the field records are quite simple and contain limited information for detailed analysis. Fortunately, the governments of all levels are increasing the attentions on field investigations and building databases of disaster information in recent years. More available information can be obtained for further applications in the future.

The accuracy of model calibration and verification is highly dependent to the available records. The historic typhoon events were used to calibrate the parameters of numerical models, including the roughness of catchments, channels and floodplains. The other typhoon or flood events were applied for model verifications. For a watershed without enough event records, the flood-prone areas, which suffered serious inundation frequently in the past, were described according to the experiences of flood managers in local governments and adopted for model verification. The procedures were conducted by watershed divisions individually. The experience applied in Sijhih City is illustrated as an example. 


\subsection{MODEL CALIBRATIONS}

Sijhih City in northern Taiwan, which is mentioned earlier, is a densely developed town in the Keelung River basin. The area suffers from flood

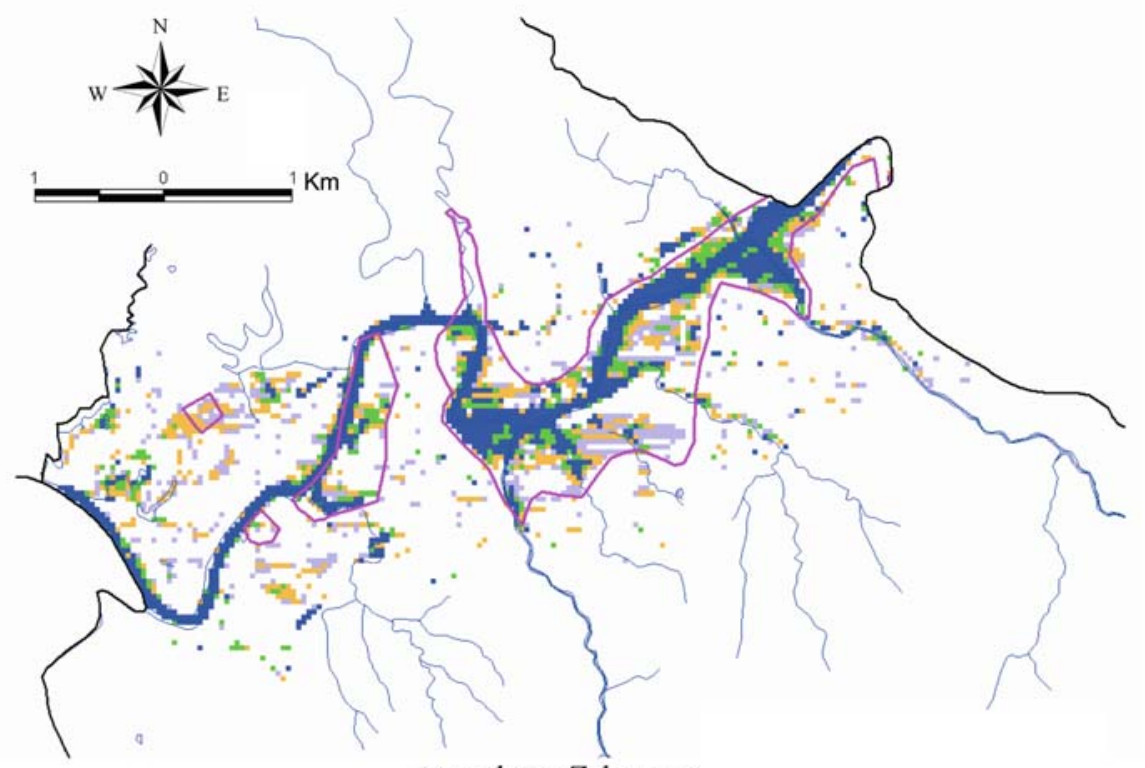

(a) typhoon Zeb event

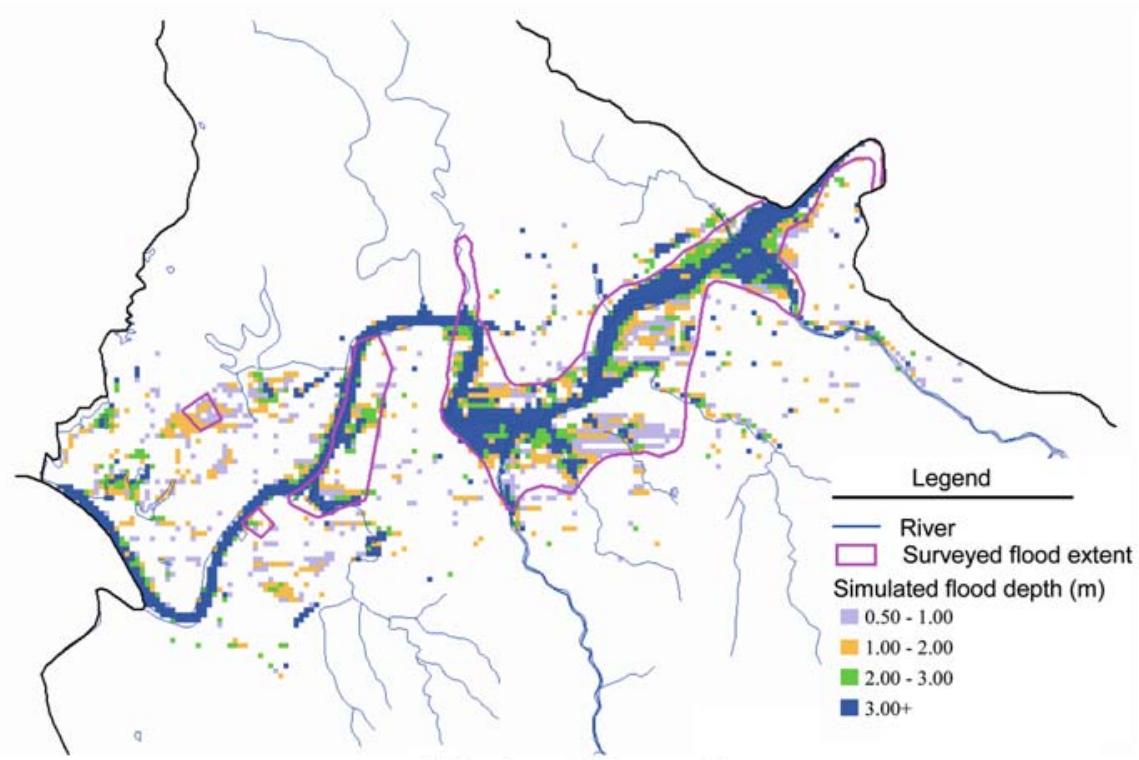

(b) typhoon Babs event

Figure 4. Model calibrations in Sijhih City. 
disasters frequently in the last decade because of the excessive development. In 1998, Typhoon Zeb and Typhoon Babs continuously invaded Sijhih City in 10 days and caused serious damage. The precipitation records of rain gauges in surrounding areas were input for numerical simulations. The grid size $40 \mathrm{~m} \times 40 \mathrm{~m}$, which is currently best available from the DEM in Taiwan, was used for computing. The flood extents and water depth ranges, surveyed by the water management authority, were used for calibrations.

Typhoon Zeb flooded 291 ha of Sijhih City with water depths varied from 0.5 to $4.0 \mathrm{~m}$. Typhoon Babs resulted in a smaller damage by 286 ha of flooded areas with depths varied from 0.5 to $3.8 \mathrm{~m}$. The flood extents of field surveys and numerical simulations of two events are shown in Figure 4. The calibrated Manning's roughness coefficients for various types of land use are listed in Table III. In common, cultivate or wood lands have the highest roughness due to the dense vegetations. On the contrast, waterways or highways have the lowest ones because there are less barriers insides for water flows.

The flooded areas and maximum inundation depths are compared in Table IV. The simulation results tend to over-estimate the flooded area and depths because the detailed information of drainage systems in the area was not available to be considered in the models. The physical phenomena of the overland flow that drains into sewers cannot be properly reflected. The water was trapped in local depressions in the simulation results, which caused over-estimated flooded areas and depths.

\subsection{MODEL VERIFICATIONS}

With the calibrated parameters, another typhoon event, the typhoon Xangsane on Oct. 31st 2000, was adopted for model verification. Typhoon Xangsane brought torrential rainfall and inundated 356 ha in the area. The rainfall records of the nearby rain gauges during the event were input for numerical routings. The investigated and simulated flood extents are shown in Figure 5. The flooded area and depth range are also compared in

Table III. The Manning's roughness for various types of land use for Sijhih City

\begin{tabular}{ll}
\hline Land use & Manning's roughness \\
\hline Cultivate and wood land & 0.200 \\
Highway, road & 0.030 \\
Industrial area & 0.075 \\
Park & 0.150 \\
Residential area & 0.100 \\
Waterway & 0.020 \\
Others & 0.050 \\
\hline
\end{tabular}


Table IV. Comparison of field survey and simulation results of flooded area and maximum inundation depth in Sijhih City during typhoon events

\begin{tabular}{llllll}
\hline $\begin{array}{lllll}\text { Typhoon } \\
\text { event }\end{array}$ & Recorded & & & Simulated \\
\cline { 2 - 3 } \cline { 5 - 6 } & $\begin{array}{l}\text { Area } \\
\text { (ha) }\end{array}$ & $\begin{array}{l}\text { Max. inundation } \\
\text { depth (m) }\end{array}$ & & $\begin{array}{l}\text { Area } \\
\text { (ha) }\end{array}$ & $\begin{array}{l}\text { Max. inundation } \\
\text { depth (m) }\end{array}$ \\
\hline Zeb & 291 & 4.0 & & 293.2 & 4.15 \\
Babs & 286 & 3.8 & & 287.5 & 3.93 \\
Xangsane & 356 & 7.5 & 364.8 & 8.00 \\
\hline
\end{tabular}

Table IV, which demonstrates that the numerical result has high consistency with the survey records.

Similar calibration and verification processes were carried out by other watershed divisions. For watersheds with more information, such as flood depths at specific time and locations, the parameters can be further tuned and verified. For instance, the Typhoon Nari event in 2001 induced the most severe flood disaster of Taipei City in recent years. A number of pumping stations failed to operate and many underground infrastructures were submerged due to the unexpected flood. The failing time of pumping stations and flood volumes in underground basements were recorded and

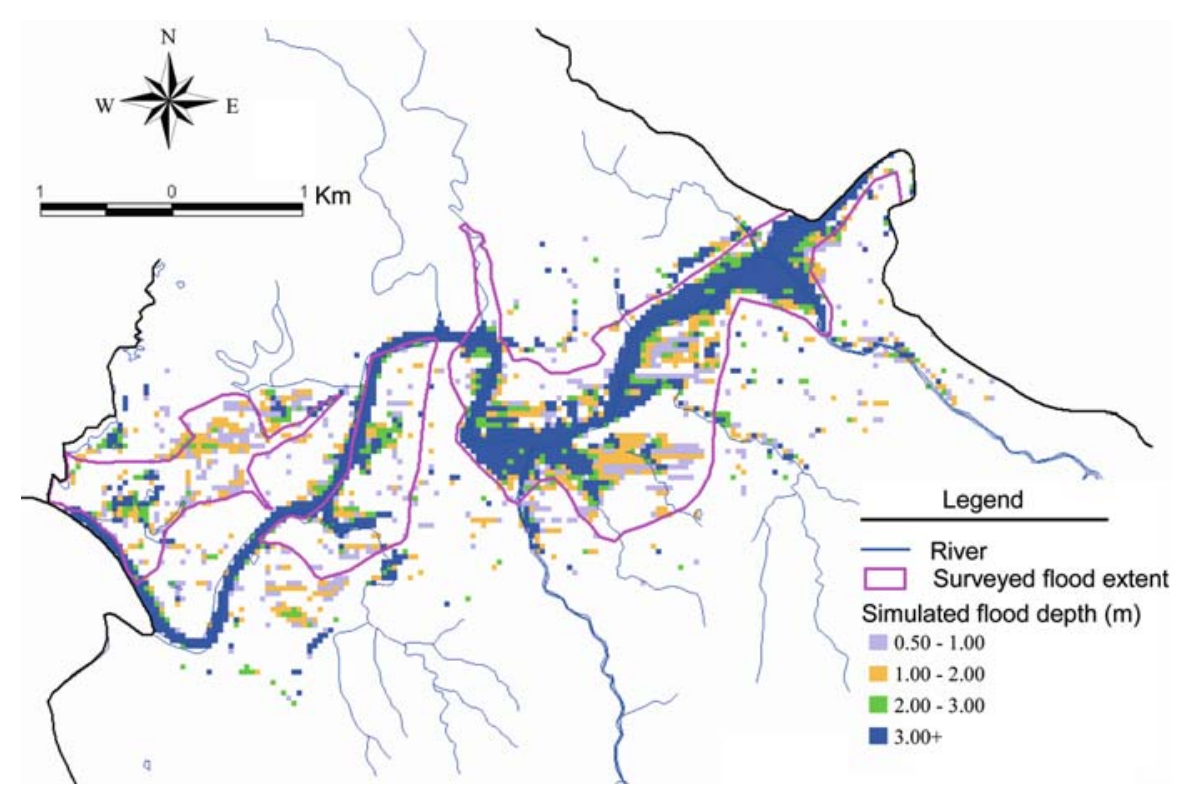

Figure 5. Model verification in Sijhih City by using the Typhoon Xangsane event. 


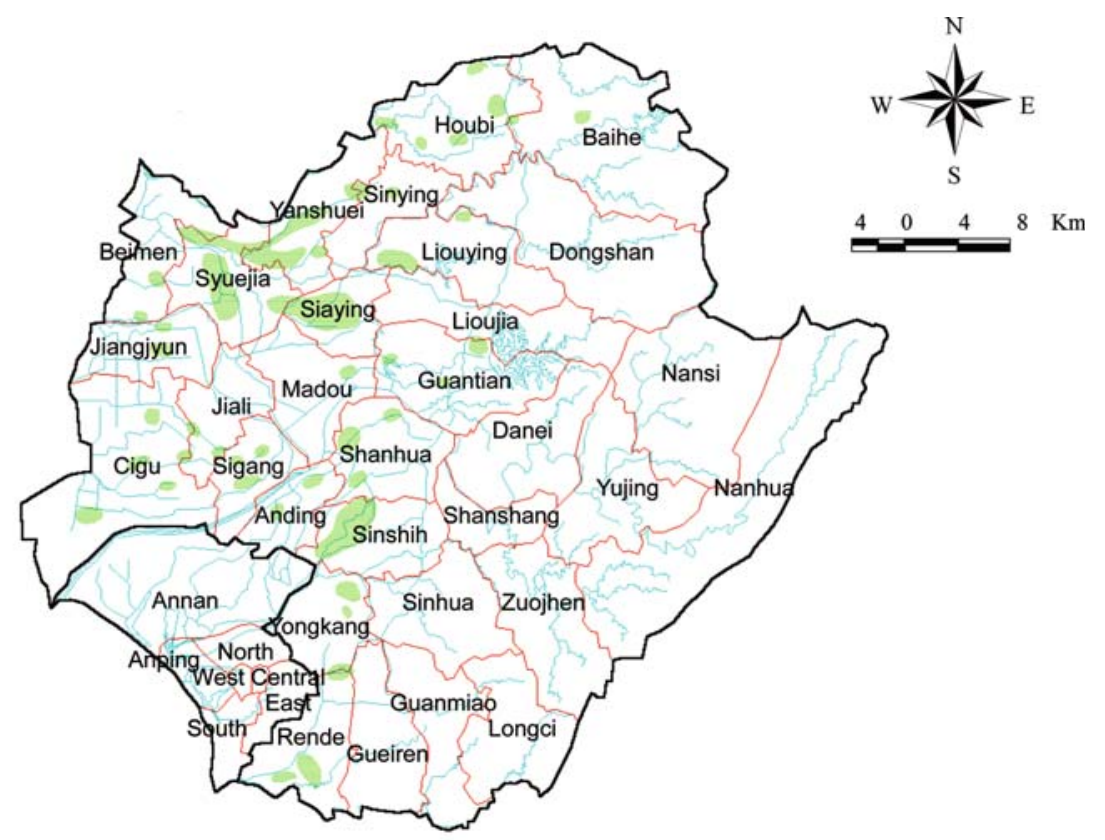

(a) The flood-prone areas delineated by the local government

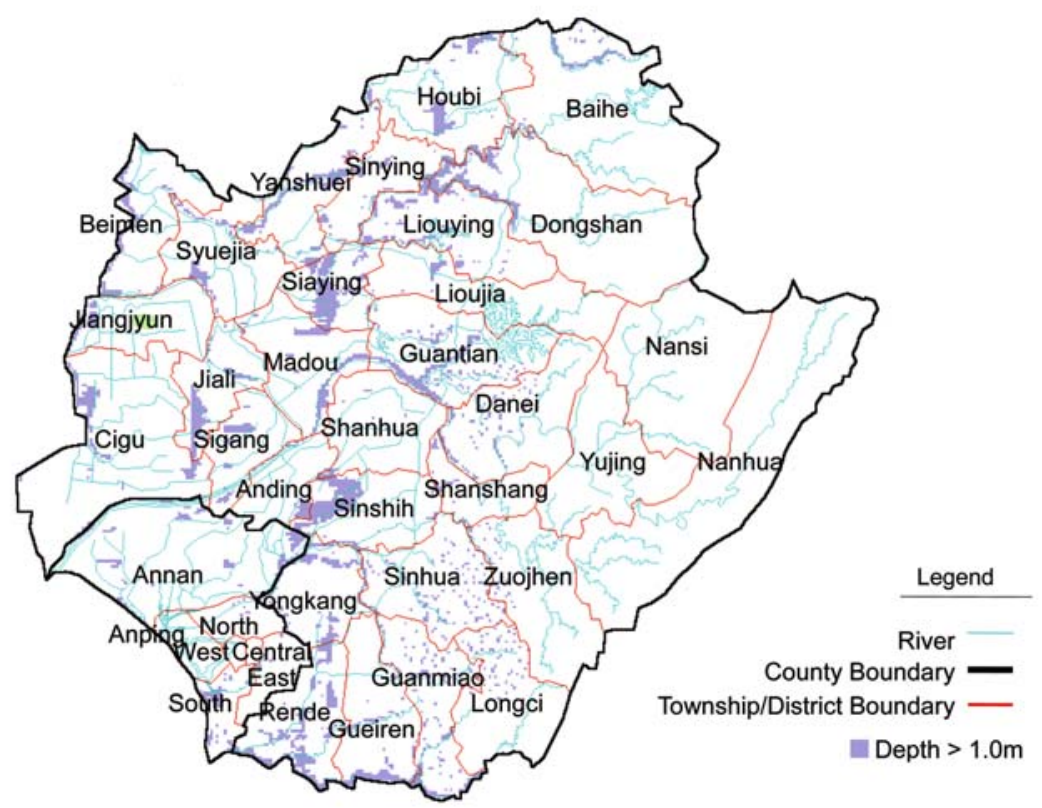

(b) Simulated flood extents of rainfall event with 5-year occurrence interval

Figure 6. The model verification in Tainan County. 
compared to the results of numerical simulations as a verification in downtown Taipei (Hsu et al., 2002; Chen et al., 2004).

In case of watersheds without complete historical inundation records of storm events, the flood-prone areas were used for model verifications. Figure 6a shows an example of the flood-prone areas delineated by the Tainan County government. Consequently, the numerical simulation result with rainfall of 5-year occurrence interval was compared to the floodprone areas. The result shown in Figure $6 \mathrm{~b}$ reveals that the inundation areas agreement with the investigated flood-prone areas.

\section{Construction of the Database}

The torrential rainfall is the major factor that leads to flood disasters in Taiwan. The flash floods that result in serious damages frequently occur about 24-h duration, thus, the design rainfall pattern of 24-h duration was applied for numerical simulations. The alternating block method (Chow, 1988) was employed to estimate the temporal distribution of the design rainfall for each watershed. Meanwhile, the real time simulation during floods by using 2-D overland flow models is difficult to achieve because the models are time-consuming. Hence, the inundation potential database was planned to be applied in emergency managements.

Table $V$. The 24-h rainfalls for different occurrence intervals in each county of Taiwan

\begin{tabular}{lllllll}
\hline \multirow{2}{*}{ County } & \multicolumn{6}{l}{ Rainfalls for occurrence intervals $(\mathrm{mm})$} \\
\cline { 2 - 7 } & 5 year & 10 year & 25 year & 50 year & 100 year & 200 year \\
\hline Changhua & 250 & 303 & 373 & 426 & 480 & 536 \\
Chiayi & 335 & 399 & 474 & 526 & 575 & 621 \\
Hsinchu & 269 & 315 & 369 & 407 & 442 & 475 \\
Hualien & 443 & 530 & 600 & 706 & 773 & 842 \\
Kaohsiung & 352 & 413 & 484 & 533 & 580 & 624 \\
Keelung & 264 & 312 & 381 & 437 & 498 & 564 \\
Miaoli & 281 & 345 & 406 & 482 & 540 & 595 \\
Nantou & 354 & 420 & 497 & 550 & 600 & 648 \\
Pingtung & 342 & 411 & 472 & 553 & 613 & 673 \\
Taichung & 354 & 420 & 497 & 550 & 600 & 648 \\
Tainan & 330 & 410 & 480 & 530 & 580 & 625 \\
Taipei & 330 & 374 & 426 & 463 & 505 & 550 \\
Taitung & 379 & 445 & 498 & 580 & 634 & 685 \\
Tauyuan & 335 & 399 & 474 & 526 & 575 & 621 \\
Yilan & 458 & 549 & 654 & 728 & 797 & 863 \\
Yunlin & 236 & 276 & 322 & 354 & 385 & 413 \\
\hline
\end{tabular}


Table V shows the 24-h rainfalls for various occurrence intervals in each county of Taiwan. The rainfalls with the same occurrence interval in individual counties are quite different. In addition, the rainfall-frequency analysis results fluctuated due to the increasing extreme rainfall events in recent years. Meanwhile, the uniform quantity of rainfall conditions is more understandable to the emergency managers. The specific amounts of rainfall were adopted for simulations instead of using the rainfalls with different occurrence intervals. Four hyetographs with equal intervals, namely, $150,300,450$ and $600 \mathrm{~mm}$ of total rainfall in $24 \mathrm{~h}$, were selected as the design rainfalls. During floods, the emergency managers can easily compare the current rainfall conditions with the design rainfalls in order to estimate the flood extents and depths from by using the inundation potential database. The equivalent occurrence intervals and exceedence probabilities of design rainfalls for each county are listed in Table VI. Accordingly, the managers can also understand the flood risks of different rainfall scenarios by referencing the table.

The spatial variation of rainfall is assumed uniform distributed within the same watershed for simplifying the scenarios. The cases with different spatial distributions can be considered in the future plans to expand the

Table VI. The equivalent occurrence interval (EOI) and exceeding probability (EP) for various 24-h rainfalls in each county of Taiwan

\begin{tabular}{|c|c|c|c|c|c|c|c|c|}
\hline \multirow[t]{2}{*}{ County } & \multicolumn{2}{|c|}{$150 \mathrm{~mm}$} & \multicolumn{2}{|c|}{$300 \mathrm{~mm}$} & \multicolumn{2}{|c|}{$450 \mathrm{~mm}$} & \multicolumn{2}{|c|}{$600 \mathrm{~mm}$} \\
\hline & $\begin{array}{l}\text { EOI } \\
\text { (year) }\end{array}$ & $\mathrm{EP}$ & $\begin{array}{l}\text { EOI } \\
\text { (year) }\end{array}$ & $\mathrm{EP}$ & $\begin{array}{l}\text { EOI } \\
\text { (year) }\end{array}$ & $\mathrm{EP}$ & $\begin{array}{l}\text { EOI } \\
\text { (year) }\end{array}$ & $\mathrm{EP}$ \\
\hline Changhua & 1.4 & 0.698 & 9.8 & 0.102 & 67 & 0.015 & 457 & 0.002 \\
\hline Chiayi & $<1$ & $>1$ & 2.9 & 0.345 & 20 & 0.050 & 140 & 0.007 \\
\hline Hsinchu & $<1$ & $>1$ & 8.0 & 0.125 & 115 & 0.009 & $>500$ & $<0.002$ \\
\hline Hualien & $<1$ & $>1$ & 1.3 & 0.769 & 5.0 & 0.200 & 20 & 0.050 \\
\hline Kaohsiung & $<1$ & $>1$ & 2.2 & 0.455 & 17 & 0.059 & 132 & 0.008 \\
\hline Keelung & $<1$ & $>1$ & 8.0 & 0.125 & 55 & 0.018 & 360 & 0.003 \\
\hline Miaoli & 1.0 & 1.00 & 6.0 & 0.167 & 35 & 0.029 & 205 & 0.005 \\
\hline Nantou & $<1$ & $>1$ & 2.3 & 0.435 & 15 & 0.067 & 100 & 0.010 \\
\hline Pingtung & $<1$ & $>1$ & 3.2 & 0.313 & 17 & 0.059 & 90 & 0.011 \\
\hline Taichung & $<1$ & $>1$ & 3.2 & 0.313 & 22 & 0.046 & 150 & 0.007 \\
\hline Tainan & $<1$ & $>1$ & 2.8 & 0.357 & 19 & 0.053 & 130 & 0.008 \\
\hline Taipei & $<1$ & $>1$ & 4.8 & 0.208 & 40 & 0.025 & 330 & 0.003 \\
\hline Taitung & $<1$ & $>1$ & 1.8 & 0.556 & 11 & 0.091 & 68 & 0.015 \\
\hline Tauyuan & $<1$ & $>1$ & 2.9 & 0.345 & 20 & 0.050 & 140 & 0.007 \\
\hline Yilan & $<1$ & $>1$ & 1.1 & 0.909 & 4.0 & 0.250 & 17 & 0.059 \\
\hline Yunlin & $<1$ & $>1$ & 17 & 0.059 & 400 & 0.0025 & $>500$ & $<0.002$ \\
\hline
\end{tabular}


database. The flood defense structures such as levees, pumping stations, and flood proof gates were assumed working normally without failure in the simulations.

The results were in digital format and coordinated into a database, which can be queried by setting user-defined criteria for analyses, and be transformed into different forms for further applications with different purposes. The county government is the basic authoritative unit for emergency response in Taiwan. Therefore, the database was approved by the Executive Yuan, ROC, and published as inundation potential maps of counties for flood managements in local governments. Figure 7 shows the island-wide inundation potential map for $600 \mathrm{~mm}$ of rainfall in $24 \mathrm{~h}$ and Table VII shows the statistics of inundation potential areas of four design rainfalls for each county. The southwest counties, Tainan and Yunlin, have larger flooded areas than other counties under the same total rainfall conditions. More than $1000 \mathrm{~km}^{2}$ of area in the counties could be inundated when total rainfall in $24 \mathrm{~h}$ reaches $600 \mathrm{~mm}$. It helps the central government to set up the land use policy in national scale to reduce flood risks of the area. The local governments and water

Table VII. The inundation potential areas for various 24-h rainfalls in each county of Taiwan

\begin{tabular}{lcrrr}
\hline County & \multicolumn{2}{l}{ Areas for 24-h rainfalls $\left(\mathrm{km}^{2}\right)$} & \\
\cline { 2 - 5 } & $150 \mathrm{~mm}$ & $300 \mathrm{~mm}$ & $450 \mathrm{~mm}$ & $600 \mathrm{~mm}$ \\
\hline Changhua & 25.2 & 96.2 & 194.1 & 288.6 \\
Chiayi & 48.8 & 143.0 & 227.9 & 300.9 \\
Hsinchu & 14.1 & 29.6 & 41.8 & 59.8 \\
Hualien & 22.0 & 34.9 & 47.4 & 57.6 \\
Kaohsiung & 35.8 & 97.8 & 153.7 & 199.3 \\
Keelung & 2.3 & 4.6 & 5.8 & 6.4 \\
Miaoli & 28.2 & 45.7 & 60.7 & 73.4 \\
Nantou & 9.5 & 20.8 & 32.6 & 47.8 \\
Pingtung & 90.5 & 160.4 & 218.8 & 235.0 \\
Taichung & 16.8 & 44.2 & 77.0 & 108.2 \\
Tainan & 117.8 & 306.6 & 456.2 & 578.6 \\
Taipei & 23.1 & 40.6 & 57.8 & 77.7 \\
Taitung & 14.4 & 27.9 & 37.1 & 44.6 \\
Tauyuan & 11.0 & 30.8 & 53.9 & 149.8 \\
Yilan & 5.2 & 42.1 & 74.6 & 99.3 \\
Yunlin & 68.7 & 221.2 & 360.2 & 463.6 \\
\hline
\end{tabular}


management authority may as well allocate more resources on the area for hazard mitigation.

Moreover, the digital database makes it easy to generate the hazard maps in different scales for distinct applications. Figure 8 shows the inundation potential maps, overlapped with the township division layers, of Tainan County on the southwest part of the island. The information helps the county government realizing flood potential within its administration. The east regions of the county are upstream mountainous areas with lower

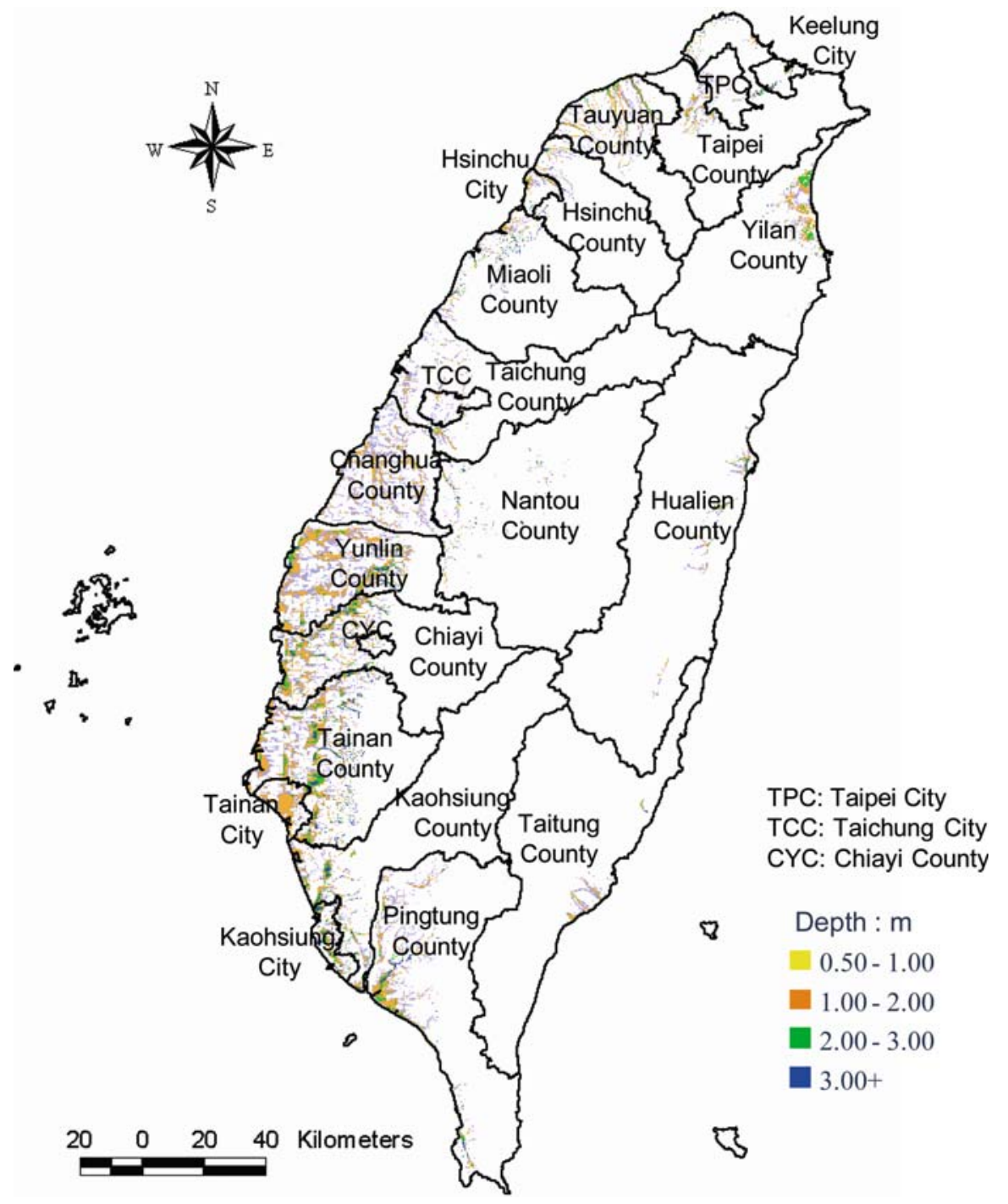

Figure 7. The inundation potential map of Taiwan (with $600 \mathrm{~mm}$ rainfall in $24 \mathrm{~h}$ ). 
flood risks. On the contrast, the Sinshih Township, where the Southern Taiwan Science Park (STSP) is located in, and the southwest costal regions are identified as the area with the highest flood risks. Tables VI and Table VII display that there is $117.8 \mathrm{~km}^{2}$ of area in the county could be inundated more than once in a year and $578.6 \mathrm{~km}^{2}$ has a exceedence probability 0.008 of being flooded per year.

The STSP is Taiwan's second science-based industrial park, specializing in microelectronics, semiconductors, and agricultural biotechnology industries. The park was scheduled as two stages for development. The first stage with 638 ha evolution area was started at 1997 and will be completed by the end of 2005. The second stage with another 400 ha developing area was planned to be finished in 2010. The base site of STSP was selected before the approving of inundation potential database. Owing to lacking of the flood-related information and historical records, the flood risk was not well-considered until a serious flood event happened in 1998 when the

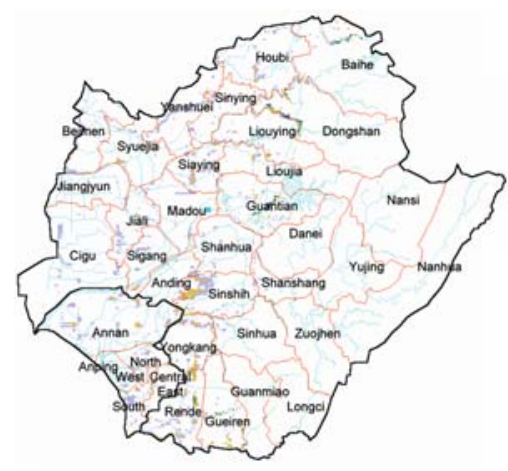

(a) $150 \mathrm{~mm}$ rainfall in 24 hours

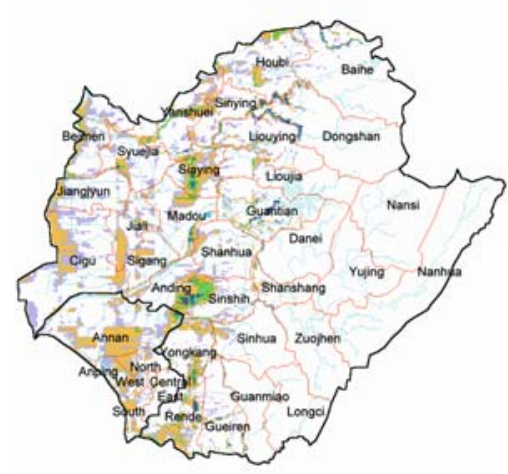

(c) $450 \mathrm{~mm}$ rainfall in 24 hours

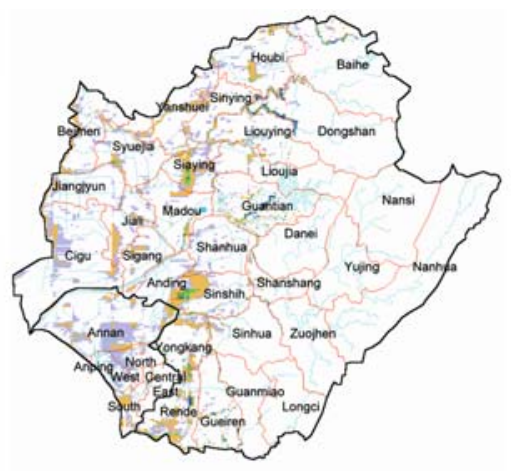

(b) $300 \mathrm{~mm}$ rainfall in 24 hours

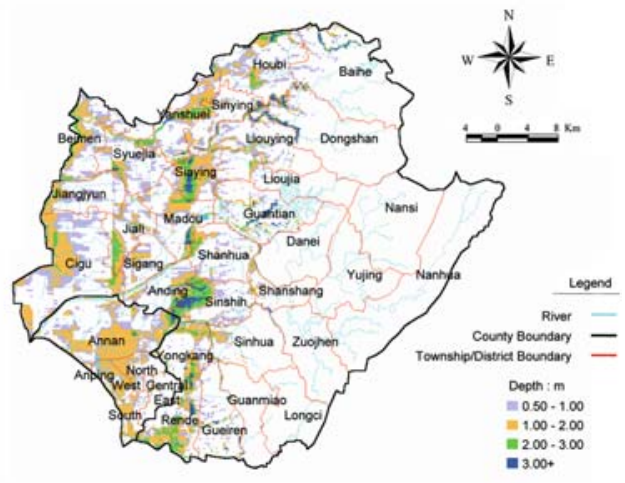

(d) $600 \mathrm{~mm}$ rainfall in 24 hours

Figure 8. The inundation potential maps of Tainan County. 


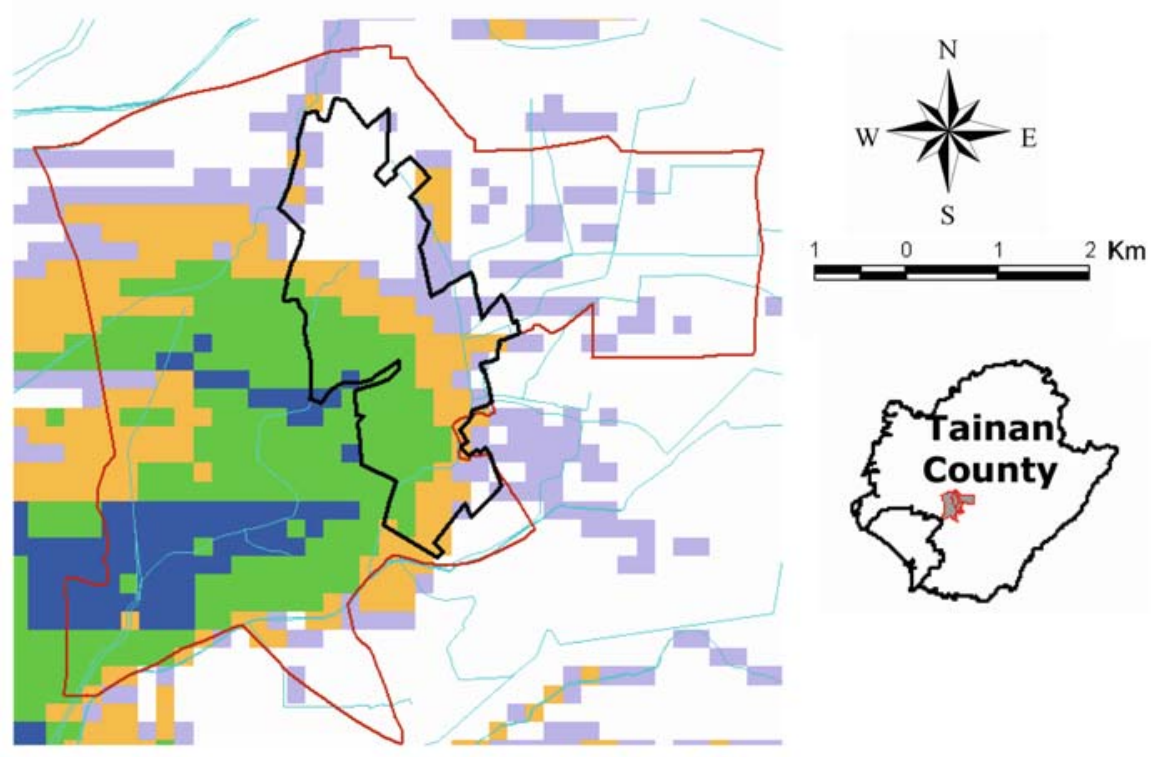

(a) without flood-proofing measures

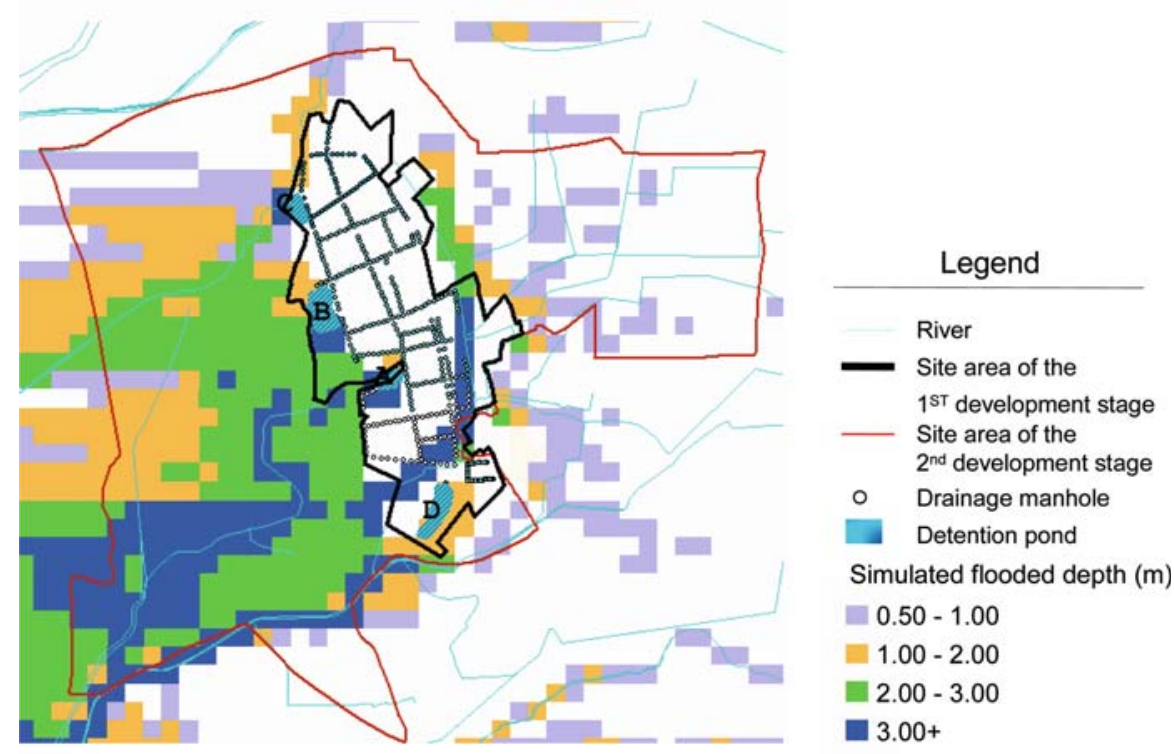

(b) with flood-proofing measures

Figure 9. The inundation potential map of STSP in Tainan County (with $600 \mathrm{~mm}$ rainfall in $24 \mathrm{~h}$ ). 
park was under construction. Figure 9a displays the detailed inundation potential around the base area of STSP. The high flood risk could affect the normal operations of investors.

The government spent tremendous efforts and budgets on the flood-proofing measures for the first development stage, including raising the ground surface elevation of the base area, building storm drainage systems and detention ponds. The ground surface of the base area of the first development stage was elevated to prevent the flood with 200-year occurrence interval. Four storm sewer systems, designed by rainfall with 25 -year occurrence interval, were constructed to collect the surface runoffs within the park. Four detention ponds with total areas of 45 ha were built, at outlets of each sewer system, for reducing the peak outflow discharges which may impact the downstream regions. Figure $9 \mathrm{~b}$ demonstrates that the floodproofing measures, which cost 53 million U.S. dollars for the first development stage, successfully reduced the flood risk. The flooded area of the scenario with $600 \mathrm{~mm}$ daily total rainfall was reduced from 484 to 160 ha, where the flooded locations after the flood-proofing measures are the detention ponds and drainage improvement.

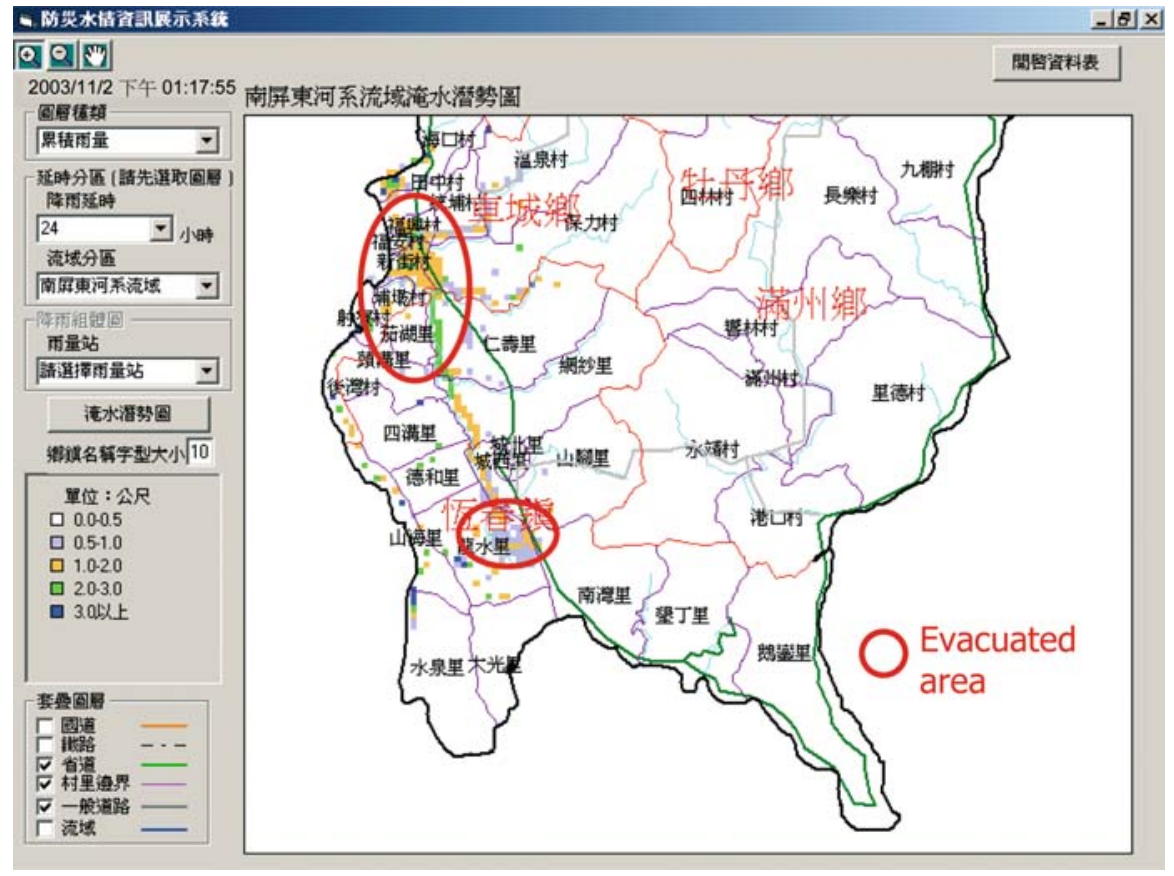

Figure 10. The inundation potential map selected by the decision support system and the evacuated area of the south Pingtung County during the Typhoon Melor event. 


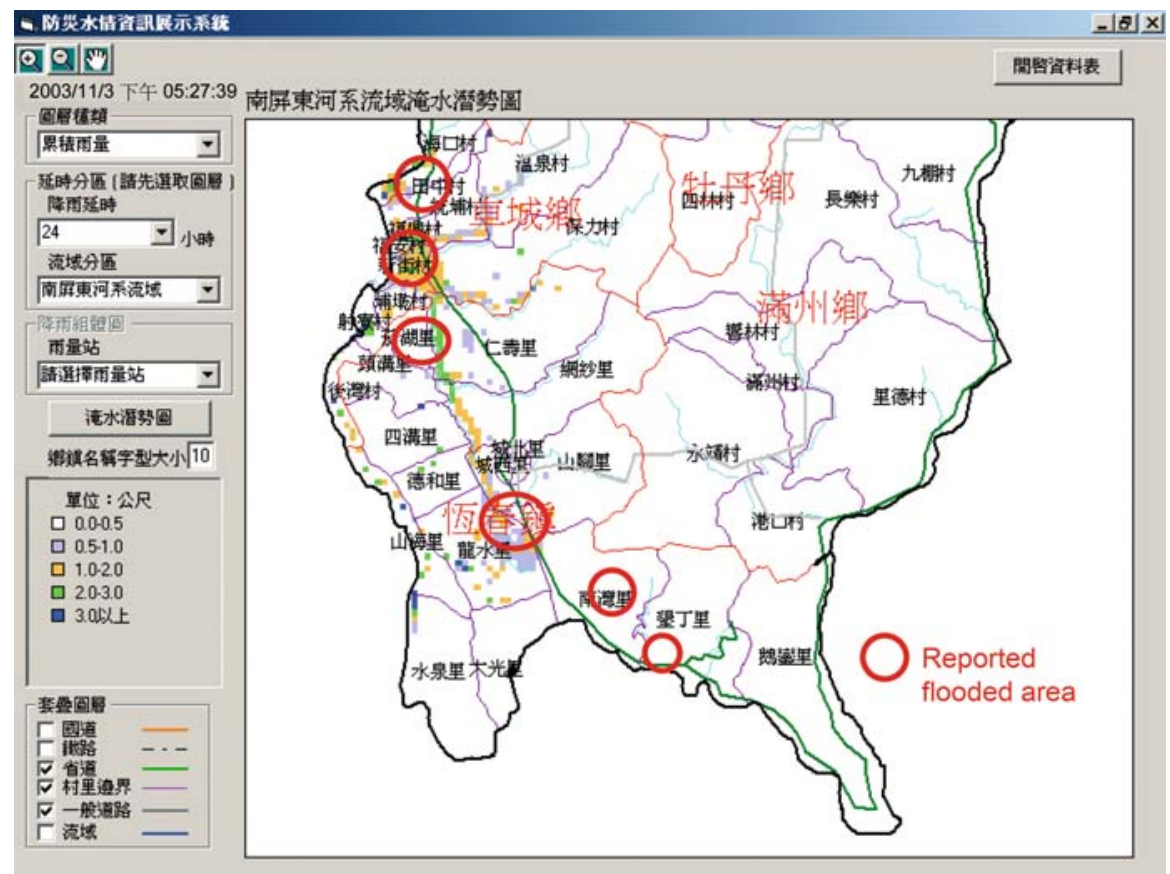

Figure 11. The inundation potential map selected by the decision support system and the reported flood area of south Pingtung County during the Typhoon Melor event.

Currently, the government continues planning the follow-up floodproofing measures by using the inundation potential database to mitigate the flood hazard for the base area of the second development stage.

\section{Applications}

\subsection{LAND USE MANAGEMENT}

Both the unlimited development of Sijhih City and the site selection of STSP were painful experiences due to lacking of inundation potential information. To avoid recommitting again in the future, the inundation potential database has taken an important role in the floodplain managements. Nowadays, the government indicates the inundation potential, by applying the database, for urban planning to keep from inappropriate land use. The areas with high flood risk are announced by the authorities as evolution-forbidden. 


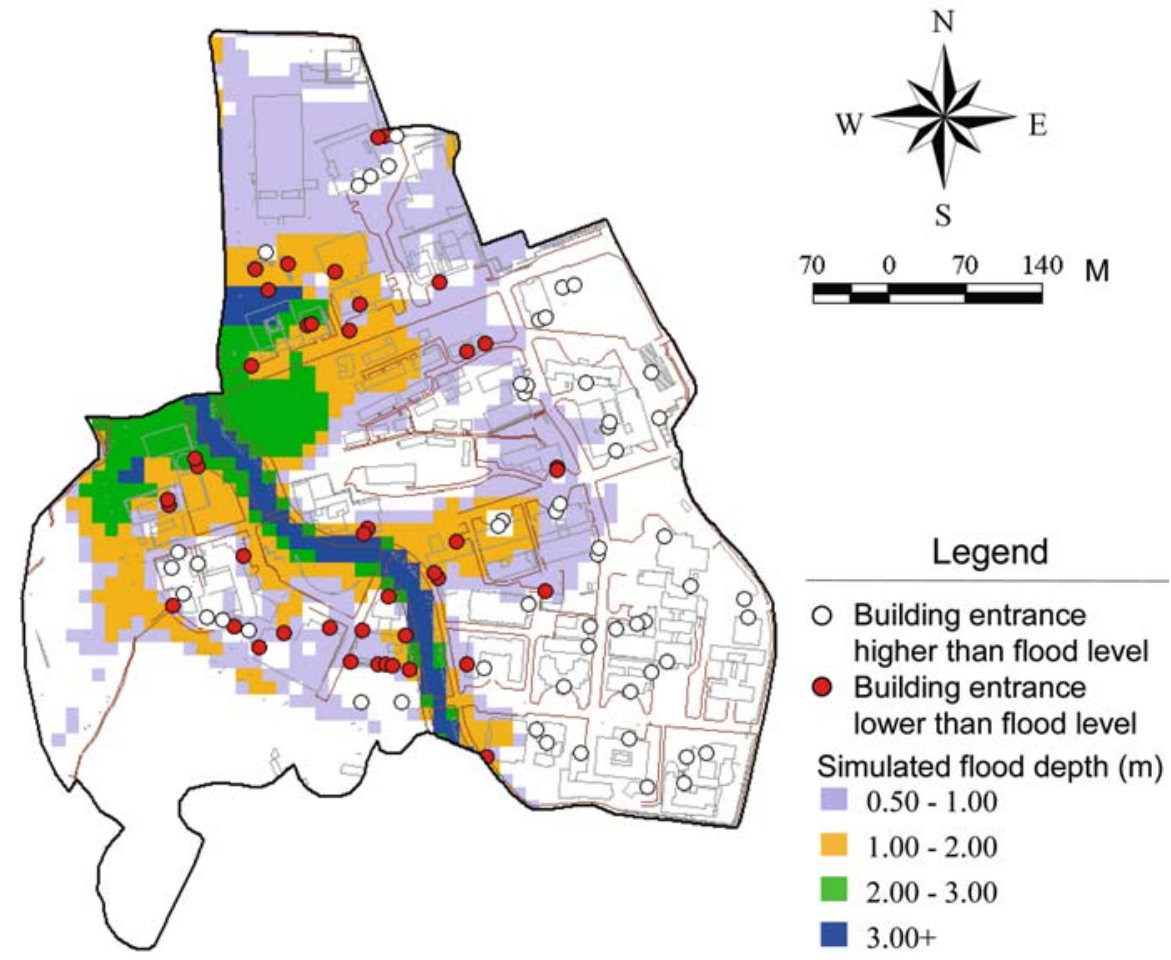

Figure 12. The application of inundation potential to the Academia Sinica.

\subsection{FLOOD WARNING AND EMERGENCY RESPONSE}

The inundation potential database also helps the governments to set the emergency response strategies, such as rescuing resources allocating, evacuating routes and shelters planning, to strengthen the preparedness for flood prevention.

For emergency responses during floods, a decision support system (DSS) is developed to help the commanders identifying the inundation potential. The island-wide real time precipitation records are collected and updated with a $10 \mathrm{~min}$ frequency by the system. The real time rainfall conditions are analyzed and compared to the design rainfall patterns that used for building the inundation potential database. The inundation potential information which was generated by the closest pattern to the real time rainfall condition is automatically picked up from the database by watershed divisions individually in the system. The information is displayed as a map that overlapped with other spatial information layers, such as streets, rivers, buildings and districts. Once the inundation potential risks are identified, there are usually 2 or $3 \mathrm{~h}$ before floods occurring. Emergency managers can issue the flood warning to residents in high flood 
risk areas and evacuate them to safe shelters through an appropriate route.

Figure 10 shows the inundation potential map of south Pingtung County, the most southern county of Taiwan, that was automatically selected by the DSS during the Typhoon Melor event in 2003. The emergency managers issued warnings and evacuated residents in the high inundation potential areas by using the DSS. Figure 11 displays the reported flooded area of the same region. It reveals that the application of inundation potential map successfully helped the commanders to reduce the damage of flood.

\subsection{FLOOD-PROOFING MEASURES}

As mentioned earlier, the inundation potential information successfully helped the government to improve the inundation problem of STSP. Another application for enhancing the flood-proofing measure of existing buildings is described as followed.

The Academia Sinica, a famous research institute in Taiwan, suffered a tremendous loss caused by the flood brought by Typhoon Nari in 2001. Dozens of building were submerged and many valuable books, equipments and research records were damaged. After the event, the administrator of the Academia Sinica decided to enhance the flood-proofing measures of

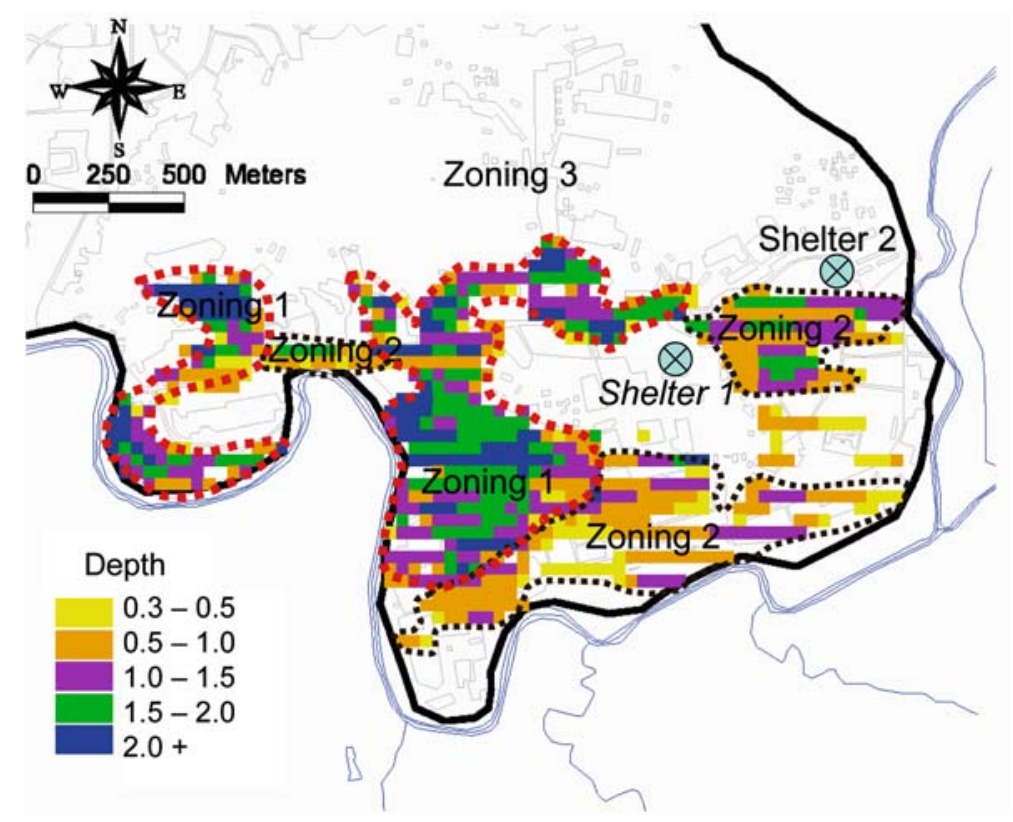

Figure 13. The flood risk zonings and emergency shelters in the Mujha area. 
buildings with the protection of 200-year flood. The surface elevations in the academy area and heights of building entrances were surveyed. Hence, the inundation potential in the area was updated by using higher grid resolution $20 \mathrm{~m} \times 20 \mathrm{~m}$ and rainfalls with different occurrence intervals. By overlapping the inundation potential with the entrance elevations, the building entrances lower than the flood level were clearly identified in Figure 12. The information helped the administrator determining flood proof measures of the Academia Sinica.

\subsection{FLOOD RISK ZONING}

Figure 13 demonstrates the inundation potential map of the Mujha area, a district in southern Taipei, with $600 \mathrm{~mm}$ total rainfall in $24 \mathrm{~h}$. The area is too densely developed to build any flood control structures. Hence, the non-structural measures must be conducted. Accordingly, the area is categorized into 3 classes of zoning based on the inundation potential maps. The Zoning 1 has the highest risk during floods. The citizens living in Zoning 1 are the first ones on the flood emergency rescuing list. They will be evacuated to the nearest shelters, where are public buildings selected with lowest risk of flood. Then, the Zoning 2 would be the next for rescuing and resources allocating.

\subsection{DAMAGE ESTIMATING AND FLOOD INSURANCE}

After the flood events, in addition to the investigation of flood extents and depths in the affected areas, the post flood questionnaire surveys might also be proceeded among the individuals and communities to estimate the economic damages caused by flood (Dutta et al., 2001). The investigations build the database of stage-damage functions. Incorporating with the database of inundation maps, the potential losses accompanying with the flood scenarios could be evaluated. The information helps decision makers for setting proper flood mitigation measures to reduce the damage losses. Besides, it could also be used for the flood insurance programs to determine the insurance premium rates.

\section{Conclusions}

The inundation potential database of Taiwan was conducted by numerical simulations of models. It provides important information for flood hazards mitigation and helps the public to realize the potential flood risk of the environment. The flood defense authorities and the governments of different levels have adopted the information for implementing the flood mitigation measures and flood defense strategies. 


\section{Acknowledgements}

The study was supported by the National Science Council, Executive Yuan, ROC. Valuable information and historical records are provided by the National Central University, the Central Weather Bureau, the Water Resources Agency, and the local governments. The authors are grateful for their considerable helps.

\section{References}

Abbott, M. B.: 1998, Computational Hydraulics, Ashgate Publishing Company, Vermont, pp. $59-62$.

Al-Sabhan, W., Mulligan, M., and Blackburn, G. A.: 2003, A real-time hydrological model for flood prediction using GIS and the WWW, Computers, Environ. Urban Syst. 27, 9-32.

Bae, D. H., Georgakakos, K. P., and Nanda, S. K.: 1995, Operational forecasting with realtime databases, J. Hydraulic Eng. - ASCE 121(1), 49-60.

Bishop, W. A. and Catalano, C. L.: 2001, Benefits of two-dimensional modelling for urban flood projects. In: 6th Conference on Hydraulics in Civil Engineering, Hobart, Australia.

Bohm, H. R., Haupter, B., Heiland, P., and Dapp, K.: 2004, Implementation of flood risk management measures into spatial plans and policies, River Res. Appl. 20(3), 255-267.

Burby, R. J.: 2001, Flood insurance and floodplain management: the US experience, Environ. Hazards 3, 111-122.

Cabinet Office: 2003, Disaster Management in Japan, Cabinet Office Government of Japan (in Japanese).

Chang, T. J., Hsu, M. H., Teng, W. H., and Huang, C. J.: 2000, A GIS-assisted distributed watershed model for simulating flooding and inundation, J. Am. Water Resour. Assoc. 36(5), 975-988.

Changnon, S. A.: 1998, The historical struggle with floods on the Mississippi River basin Impacts of recent floods and lessons for future flood management and policy, Water Int. 23(4), 263-271.

Chen, S. H., Hsu, M. H., and Chen, T. S.: 2004, The integrated inundation model for urban drainage basins. In: 5th International Conference on Sustainable Techniques and Strategies in Urban Water Management, Lyon, France.

Chow, V. T.: 1988, Applied Hydrology, McGraw-Hill Book Company, New York, pp. 465470.

Cunge, J. A., Holly, F. M. and Verwey, A.: 1980, Practical Aspects of Computational River Hydraulics, Pitman Publishing Ltd., London, U.K.

Djordjevic, S., Prodanovic, D., and Maksimovic, C.: 1999, An approach to simulation of dual drainage, Water Sci. Technol. 39(9), 95-103.

Dutta, D., Herath, S., and Musiake, K.: 2001, Direct flood damage modeling towards urban flood risk management. In: Joint Workshop on Urban Safety Engineering 2001. Thailand, Asian Institute of Technology.

Gunes, A. E. and Kovel, J. P.: 2000, Using GIS in emergency management operations, J. Urban Plan. Dev. - ASCE 126(3), 136-149.

Harman, J., Bramley, M. E., and Funnell, M.: 2002, Sustainable flood defence in England and Wales, Proc. Inst. Civil Eng. - Civil Eng. 150, 3-9.

Hooijer, A., Klijn, F., Pedroli, G. B. M., and Van Os, A. G.: 2004, Towards sustainable flood risk management in the Rhine and Meuse river basins: synopsis of the findings of IRMASPONGE, River Res. Appl. 20(3), 343-357. 
Hooper, B. P. and Duggin, J. A.,: 1996, Ecological riverine floodplain zoning, Land Use Policy 13(2), 87-99.

Hsu, M. H.: 1992, Simulation of inundation with overflow on levee along Keelung River. In: The CCNAA-AIT Joint Seminar on Prediction and Damage Mitigation of Meteorologically Induced Natural Disasters, Taipei, Taiwan.

Hsu, M. H.: 1998, Inundation Study for Stations and Depots of Taiwan High Speed Rail, Hydraulic Research Laboratory, National Taiwan University.

Hsu, M. H., Chen, S. H., and Chang, T. J.,: 2002, Dynamic inundation simulation of storm water interaction between sewer system and overland Flows, J. Chin. Inst. Eng. 25(2), 171-177.

Hsu, M. H., Fu, J. C., and Liu, W. C.,: 2003, Flood routing with real-time stage correction method for flash flood forecasting in the Tanshui River, Taiwan, J. Hydrol. 283(1-4), 267-280.

Hsu, M. H., Lai, J. S., and Yen, C. L.: 1990, Two-dimensional inundation model for Taipei City. In: Proceedings of the Fifth International Conference on Urban Storm Drainage, Osaka, Japan

Hsu, M. H., Teng, W. H., and Wu, F. C.,: 1998, Inundation models for the Pa-chang creek basin in Taiwan, Proc. Natl. Sci. Council ROC 22(2), 279-289.

Huber, W. C.: 1975, Model for Storm Water Strategies, APWA Reporter.

Huber, W. C. and Dickinson, R. E.: 1988, Storm Water Management Model. User's Manual Ver. IV, U. S. Environmental Protection Agency.

Klijn, F., Van Buuren, M., and Van Rooij, S. A. M.: 2004, Flood-risk management strategies for an uncertain future: Living with Rhine river floods in the Netherlands, Ambio 33(3), $141-147$

Lee, K. T., Yu, W. S., Yang, M. S., and Shih, H. M.: 1999, The Analysis of Flood Disaster in Sijhih Area During Typhoon Zeb and Babs Events, Department of River and Harbor Engineering, National Taiwan Ocean University (in Chinese).

Lin, L.: 2002, The Statistical Analysis on Natural Disasters Taiwan-Fuchien Area, MOI Statistical information service (in Chinese).

Lowe, A. S.,: 2003, The federal emergency management agency's multi-hazard flood map modernization and the national map, Photogram. Eng. Remote Sensing 69(10), 1133-1135.

Middelkoop, H., van Asselt, M. B. A., van't Klooster, S. A., van Deursen, W. P. A., Kwadijk, J. C. J., and Buiteveld, H.: 2004, Perspectives on flood management in the Rhine and Meuse rivers, River Res. Appl. 20(3), 327-342.

Murphy, D.: 2003, Strategy for Flood Risk Management (2003-2008), Environment Agency, U.K.

National Science Foundation: 1980, A Report on Flood Hazard Mitigation, National Science Foundation.

Sijhih City Household Registration Office.: 2004, The Household and Total Population Statistic Information of Sijhih City, Sijhih City Household Registration Office, Taipei County Government, Taipei County (in Chinese).

Simonovic, S. P.: 2002, Two new non-structural measures for sustainable management of floods, Water Int. 27(1), 38-46.

Subramaniam, C. and Kerpedjiev, S.: 1998, Dissemination of weather information to emergency managers: a decision support tool, IEEE Trans. Eng. Manage. 45(2), 106-114.

Sullivan, A., Ternan, J. L., and Williams, A. G.: 2004, Land use change and hydrological response in the Camel catchment, Cornwall, Appl. Geogr. 24(2), 119-137.

U.S. Army Corps of Engineers Hydrologic Engineering Center: 1992, HEC-1 Hydrograph Package, Water Resources Support Center. 
Water Resources Agency: 2003, Hydrological Year Book of Taiwan Republic of China 2002, Part I - Rainfall, Water Resources Agency, Ministry of Economic Affairs, ISSN 0257.5442 (in Chinese).

Wu, C. M.: 1995, The regulation of river and flood defense. In: When will the Flood Disasters End? - Proceeding of Flood Disaster and Defenses Conference, Taipei, Chinatimes Cultural and Educational Foundation (in Chinese).

Yeo, S.: 2003, Flood risk management for caravan parks in New South Wales, Aust. Geogr. 34(2), 195-209.

Zerger, A. and Wealands, S.: 2004, Beyond modelling: linking models with GIS for flood risk management, Nat. Hazards 33(2), 191-208. 